\title{
ИСПОЛЬЗОВАНИЕ РЕЧЕВЫХ СИТУАЦИЙ НА НАЧАЛЬНОМ ЭТАПЕ ОБУЧЕНИЯ РУССКОМУ ЯЗЫКУ КАК ИНОСТРАННОМУ В ТЕХНИЧЕСКОМ ВУЗЕ
}

\author{
Володина Д.Н., Дроздова О.А., Замятина Е.В., Оглезнева Е.А.
}

Нацииональный исследовательский Томский политехнический университет, Tомск, e-mail: volodinadn@mail.ru В статье описывается опыт использования речевых ситуаций в практике преподавателей кафедры русского языка как иностранного Томского политехнического университета. Исследование, проведенное с опорой на метод педагогического наблюдения, подтверждает эффективность обращения к данному методическому приему для развития навыка диалогической и неподготовленной ситуативной речи. Авторы анализируют и систематизируют реальные и учебные речевые ситуации, возникающие на начальном этапе обучения русскому языку как иностранному в техническом вузе. В статье представлены этапы усвоения речевых образцов, используемых в конкретных коммуникативных ситуациях. Предложены примеры заданий, позволяющих эффективно вводить новый языковой материал в речь студентов и активный словарный запас. Статья адресована преподавателям РКИ, студентам-филологам и всем, интересующимся вопросами методики преподавания русского языка как иностранного.

Ключевые слова: речевая ситуация, ситуативное общение, методика преподавания русского языка как иностранного, речевой образец.

\section{USING SPEECH SITUATIONS AT THE INITIAL STAGE OF TEACHING RUSSIAN AS A FOREIGN LANGUAGE AT THE TECHNICAL HIGHER EDUCATION INSTITUTION}

\author{
Volodina D.N., Drozdova O.A., Zamyatina E.V., Oglezneva E.V. \\ National Research Tomsk Polytechnic University,Tomsk, e-mail: volodinadn@mail.ru
}

The article describes the experience of using speech situations in the teacher`s practice at the Department of Russian as a Foreign Language at Tomsk Polytechnic University. The study conducted with the use of teaching observation method confirms the efficiency of addressing this methodological tool for the development of the dialogic and situational unprepared speech. The authors analyze and systematize real and learning speech situations that occur at the initial stage of learning Russian as a foreign language at the technical higher education institution. The article presents the stages of mastering speech samples used in specific communicative situations. The proposed examples of tasks allow efficient introduction of new language material into students" speech and active vocabulary. The article is intended for RFL teachers, philology students and all those interested in the methodological issues of teaching Russian as a foreign language.

Keywords: speech situation, situational communication, methods of teaching Russian as a foreign language, speech pattern.

Ситуативность является одним из эффективных и зарекомендовавших себя принципов обучения иноязычному общению, поскольку в ситуативной речи предметное содержание представлено наглядно и конкретно, речевой материал изучается достаточно легко и непроизвольно. Его усвоение происходит в процессе деятельности: становясь активным участником речевой ситуации, обучаемый пропускает через себя новую информацию, запоминает ее и впоследствии спонтанно воспроизводит в речи. Под речевой ситуацией понимается комплекс обстоятельств и система взаимоотношений, стимулирующих речевую деятельность и погружающуих коммуникантов в соцчиокультурный контекст [4, 1].

Применение речевых ситуаций при обучении иноязычному общению обеспечивает естественную необходимость многократного повторения языкового материала и создает условия для развития навыка его грамотного отбора, подготавливая учащихся к спонтанному 
общению. Моделирование речевых ситуаций создает обстановку реального общения, вовлекая студентов в процесс коммуникации, максимально приближенный к естественным условиям. Активное обращение к речевым ситуациям повышает стремление студентов контактировать друг с другом и преподавателем, создавая тем самым условия для речевого партнерства и разрушая личностные барьеры в общении; способствует снятию тревожности и созданию психологической готовности к коммуникации (приезжая из разных стран, студенты испытывают бытовые и ментальные трудности, сложности с социальной адаптацией); дает возможность адаптироваться к новой языковой среде и реалиям страны изучаемого языка.

Умелое вплетение в ткань урока речевых ситуаций, обладающих динамикой и отражающих естественно меняющиеся обстоятельства и взаимоотношения между коммуникантами, дает возможность максимально приблизить учащихся к живому реальному общению. В то же время, как справедливо рассуждает О. Е. Сергеева, среди преподавателей русского языка как иностранного часто «нет ясного понимания механизмов действия ситуации, в результате чего возникают неудачи в использовании учебных ситуаций, и тем самым компрометируется сама идея» [6, с. 3]. По ее словам, диалог на уроке часто превращается в «говорение слов по очереди» [6, с. 3], а по причине непонимания «действующих сил» процесс создания «своих, новых ситуаций на уроке» затрудняется» [6, с. 3]. А.Б. Бирюкова также говорит о необходимости обозначить новые пути моделирования речевых ситуаций, «которые легко трансформируются и позволяют говорящему извлекать основной и дополнительный смысл из речевого контекста» [2, с. 35].

Целью данной статьи является анализ и систематизация реальных и учебных речевых ситуаций, возникающих в рамках преподавания русского языка как иностранного, и описание этапов усвоения речевых образцов, используемых в конкретных коммуникативных ситуациях.

Объектом изучения стал личный опыт авторов статьи и педагогического состава кафедры русского языка как иностранного Томского политехнического университета (73 преподавателя на апрель 2016 г.), обобщенный в специально разработанных анкетах. Исследование проводилось с опорой на методы педагогического наблюдения, педагогического эксперимента, изучения и обобщения опыта педагогов-практиков, теоретического анализа педагогических идей, социологические методы исследования (анкетирование).

Преподаватели кафедры в течение многих лет активно и успешно применяют коммуникативный метод, который, по мнению Дж. Ричардса, особо значим при обучении иностранным языкам. По мнению исследователя, иностранный язык изучается посредством 
общения, а коммуникация на основе грамматики обеспечивает наиболее эффективное обучение [7, с. 12].

Речевая ситуация - центральный методический прием коммуникативного метода, поэтому опытные педагоги со стажем работы более десяти лет, как продемонстрировало анкетирование, уделяют реальным и учебным ситуациям до 40 минут, то есть почти половину занятия. При этом речевые ситуации используются на всех этапах урока, при закреплении уже изученных разговорных тем или их повторении, что свидетельствует об эффективности ситуативной речевой деятельности для облегчения процесса усвоения речевого материала. Ожидаемый объем продуцируемого высказывания варьируется от 5-7 до 20 реплик диалога, что определяется целями и типом урока.

Анкетирование показало, что при преподавании русского языка как иностранного основу ситуативного общения могут составить следующие группы реальных речевых ситуаций: опоздание, отсутствие или болезнь учащихся, наличие или отсутствие наглядных пособий, смена аудитории, новая информация из деканата; отношения между студентами, дни рождения; резкое изменение погоды; актуальные бытовые вопросы: где находится банк, как позвонить на почту, где купить куртку, как приготовить блюдо; проблемы бытового или технического характера; мероприятие или праздник в городе или университете; вопросы культурологического и страноведческого характера; смешные, печальные или непредвиденные случаи.

Такие реальные речевые ситуации обладают стимулами к речевой деятельности, однако не решают в полной мере задачу развития коммуникативной компетенции слушателей, поскольку охватывают не все сферы речевого общения (РО). Учебные же ситуации могут выполнять функцию упражнений по подготовке к неподготовленной спонтанной речи. Достаточно ограниченный объем изучаемого лексико-грамматического материала, доступного на начальном этапе, не является препятствием для ситуативной речи. В таблице приведены некоторые типы учебных ситуаций (УC) и примеры упражнений по развитию навыка разговорной речи с их использованием.

\begin{tabular}{|c|c|c|c|c|}
\hline Сфера PO & Тип УС & $\begin{array}{l}\text { Пример } \\
\text { упражнения } \\
\text { (содержание, } \\
\text { обстоятельства и } \\
\text { речевая установка } \\
\text { УС) }\end{array}$ & Коммуниканты & \begin{tabular}{l}
\multicolumn{3}{l}{ Лексические } \\
темы и фразы \\
клише
\end{tabular} \\
\hline $\begin{array}{l}\text { Социально- } \\
\text { бытовая }\end{array}$ & $\begin{array}{l}\text { Приглашение } \\
\text { на праздник }\end{array}$ & $\begin{array}{lr}\text { «Юбилей». } & \text { Вам } \\
\text { исполняется } & 20 \\
\text { лет, пригласите } \\
\text { лучших друзей } \quad \text { и }\end{array}$ & $\begin{array}{l}\text { Студент - } \\
\text { друзья, } \\
\text { родственники }\end{array}$ & $\begin{array}{l}\text { «Идем в гости», } \\
\text { «Приглашение в } \\
\text { гости» и фразы- } \\
\text { клише по теме }\end{array}$ \\
\hline
\end{tabular}




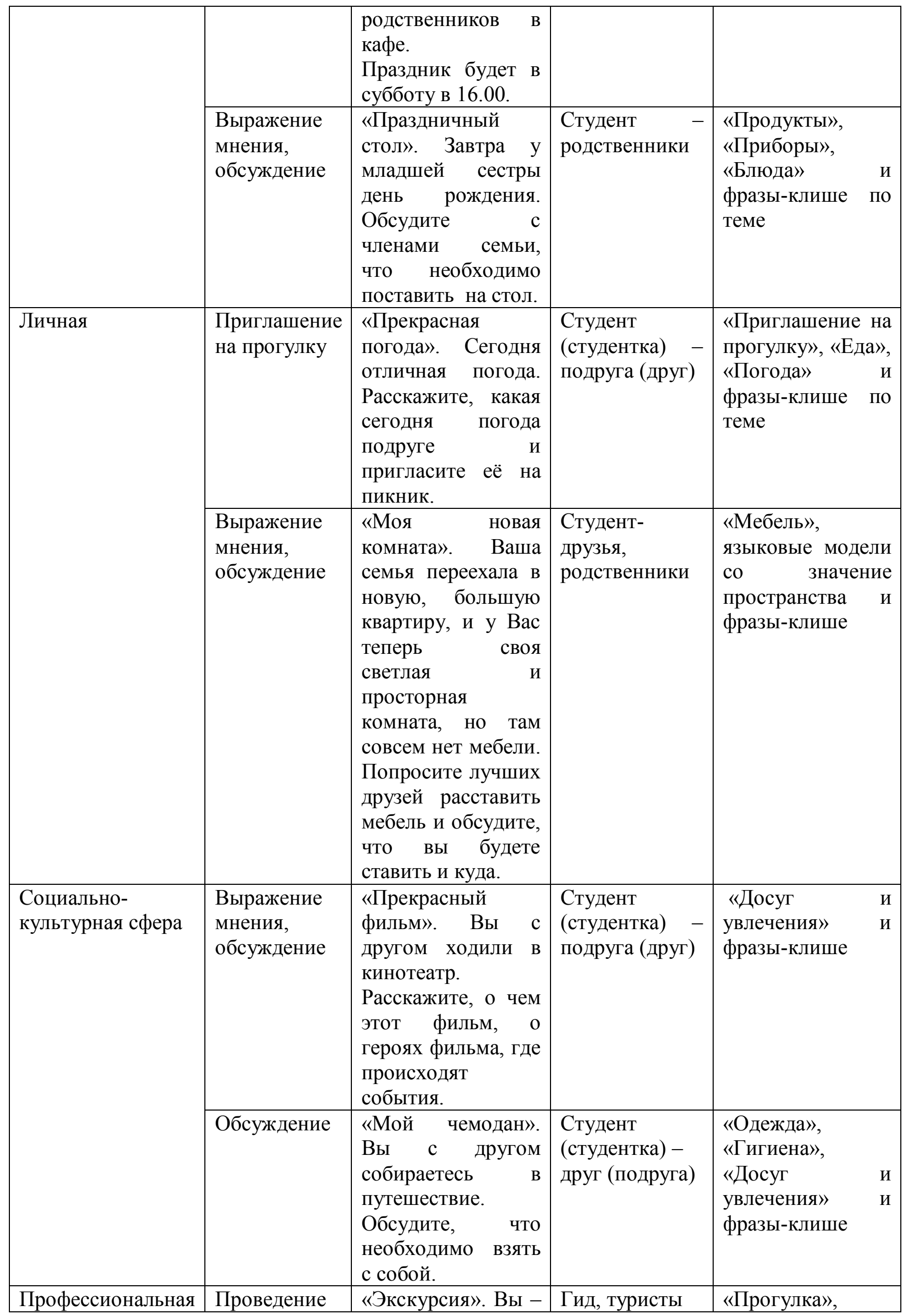




\begin{tabular}{|c|c|c|c|}
\hline сфера & экскурсии & 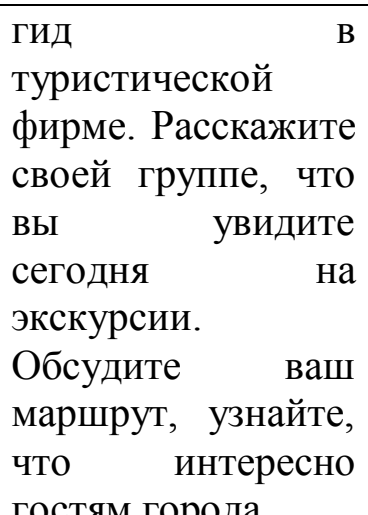 & $\begin{array}{l}\text { «Город» и фразы- } \\
\text { клише }\end{array}$ \\
\hline
\end{tabular}

Моделирование реальных и учебных речевых ситуаций в ходе занятия проходит в несколько этапов.

1. Демонстрация содержания: информация об экстралингвистических факторах (условиях, обстоятельствах и участниках разговора).

2. Мотивация, или речевой стимул (установка) как причина, побуждающая к речи, вовлекающая в речевое действие.

3. Речевая деятельность учащегося, осуществляемая с конкретной целью: сообщить информацию, уточнить, оказать воздействие на собеседника, выразить эмоциональную реакцию и др. Речевые реакции учащихся являются результатом выполнения коммуникативной задачи.

Освоение речевых образцов ситуативного общения также осуществляется постепенно по следующим примерным этапам алгоритма:

1. Подготовительный - этап демонстрации и семантизации речевых образцов, используемых в речевых ситуациях: фраз-клише или реплик ситуативного общения, которые делают речь более грамотной, понятной собеседнику, эмоционально и экспрессивно окрашенной [3]. На данном этапе предлагаются такие задания:

- прослушайте и прочитайте с правильной интонацией,

- объясните значение лексической единицы,

- используйте грамматическую конструкцию в тексте (по модели),

- прочитайте диалог по ролям.

2. Основной - выполнение многочисленных упражнений с фразами-клише, их отработка в конкретной ситуации, развитие навыка грамотного отбора языкового материала и его автоматического использования.

На основном этапе преподаватель предлагает студентам следующие типы заданий:

- прочитать текст и создать аналогичный (воспроизвести с правильным фонетическим оформлением), 
- задать вопрос в соответствии с возникающей иноязычной ситуацией общения,

- ответить на вопрос собеседника, пользуясь при построении реплики клишированными высказываниями,

- соединить реплики вопроса и ответа (в качестве ответа используются фразы-клише),

- составить и озвучить фразы-клише из данных слов,

- $\quad$ отреагировать на фразу простыми речевыми интенциями, в зависимости от ситуации общения (приветствие, просьба, благодарность, согласие, несогласие, удивление, утверждение, отрицание, возмущение и др.),

- $\quad$ подобрать фразы-клише к диалогу, при условии, что реплики одного из собеседников уже имеются в структуре,

• выбрать из предложенных реплик подходящую к данной ситуации (дефиниции),

- соотнести с соответствующим фрагментом, расширить реплики реагирования (например, объяснить причины отказа),

- построить реплику, комбинируя в ней по несколько речевых фраз, организовать набор разнохарактерных реплик в связный диалог, добавляя собственные дополнительные реплики,

- дополнить диалог недостающими репликами [5].

3. Итоговый - свободное употребление речевых образцов в новых речевых ситуациях. Имея достаточный лексический запас и отработанный навык использования фразклише, учащиеся могут активно и уверенно вступать в коммуникацию в новых речевых ситуациях, самостоятельно определяя их развитие.

Итоговый этап предполагает свободное творческое преломление материала, студентам предлагаются следующие задания:

- создать свой диалог на определенную тему,

- составить диалог к серии предлагаемых обстоятельств,

- составить диалог на основе монолога, используя употреблённые в нем клише, путем оживления и расширения последнего,

- подготовить диалог на основе предложенных ситуаций и списка обязательных для употребления фраз,

- составить тематический диалог/ситуативный из разных микроситуаций с добавлением фраз-клише,

- составить диалог к серии картинок, используя фразы клише,

- разыграть диалог по ролям. 
И естественные, и учебные речевые ситуации выступают стимулом для живой непосредственной коммуникации студентов, развивая умение продуцировать иноязычную речь в различных жизненных ситуациях. Речевые образцы в ситуативном общении разгружают оперативную память и дают возможность естественного конструирования новых самостоятельных высказываний, поэтому эффективны для развития навыка диалогической и неподготовленной ситуативной речи. Расширение диапазона использования речевых ситуаций на разных этапах урока позволяет преподавателю детальнее отрабатывать языковой материал и вводить языковые модели в активный словарный запас студентов.

\section{Список литературы}

1. Акишина А.А., Каган О.Е. Учимся учить: для преподавателей русского языка как иностранного. - М., 2004. - 256 с.

2. Бирюкова А.Б. Моделирование коммуникативно-речевых ситуаций при обучении русскому языку как иностранному в условиях неродной языковой среды // Филологические науки. Вопросы теории и практики. - Тамбов: Грамота, 2014. - No. 4 (34): в 3 ч. - Ч. III. - С. 34-37.

3. Борисова Е.Г., Латышева А.Н. Лингвистические основы РКИ (педагогическая грамматика русского языка): учебное пособие. - М., 2003. - 208 с.

4. Вайсбурд М.Л. Использование учебно-речевых ситуаций при обучении устной речи на иностранном языке. - Обнинск, 2001. - 128 с.

5. Дроздова О.А. Клиширование как один из эффективных способов обогащения иноязычной речи младших школьников// Филологические науки. Вопросы теории и практики. - 2013. - № 1 (19). - С. 77-79.

6. Сергеева О.Е. К вопросу об условиях обучения речевому общению на иностранном языке в неязыковых вузах. Гуманитарный вестник. - 2015. - № 5. - URL: http://hmbul.ru/catalog/edu/pedagog/247.html (дата обращения: 29.05.2016).

7. Richards J. Communicative Language Teaching Today. - Cambridge: Cambridge University Press, 2006. -52 p. 